\title{
Tingkat Pertumbuhan BadanItik Sasak dan Itik-Itik Pendatang Lainnya di Lombok Tengah
}

\section{(Body Growth of Sasak Ducks and Other Non Original Lombok Ducks in Centre Lombok)}

\author{
Sugeng Prasetyo, Lestari, Rahma Jan, Tapaul Rozi, L.M. Kasip \\ Laboratorium Pemuliaan Ternak Fakultas Peternakan Universitas Mataram \\ J1. Majapahit No. 62, Mataram 83125, NTB, Indonesia \\ Telepon (0370) 633603. Fax.(0370) 640592 \\ e-mail: sugengtyok@gmail.com
}

\begin{abstract}
A potential production study of Sasak duck and the non-indigenous ducks (Campbell, mojosari, MA, and alabio ducks) was carried out in Centre Lombok Regency. Research materials were 50 female DODs for each breed. The variables observed were growth rate and feed conversion. The growth rate was measured every week from started from DOD until 10 weeks old. The data obtained were analyzed by using one-way ANOVA Complete Randomized Design. Results of research: body weight gain (BWG) for all breed increased until age between 5-6 weeks after that declined. Sasak and Campbell BWG were the least. The shank length average of all breed increased 253,86\% within ten weeks. The shank length gain (SLG) for all breeds decreased steadily from the first week. The relative SLG of Sasak and MA ducks were between labia duck and Campbell ducks. The relative SLG of labor duck was highest and while that of mojosari ducks was the lowest. The average of the shank diameter gain within 10 weeks for all breeds increased $217.43 \%$. There was no shank diameter difference ( $\mathrm{P} 0.05>$ ) between Sasak ducks and the nation Lombok indigenous ducks. The average of middle finger length (MFL) of all breeds from one to 10 weeks increased 181,90\%. The relative MFL gain of Sasak and Campbell ducks were less ( $<$ < 0.05) than that of the other three breeds. The feed conversion of Sasak, Campbell ducks, mojosari, MA, and alabio were $3.60 ; 3.90 ; 4.04 ; 4.06$, and 3.66 consecutively.
\end{abstract}

Key words: sasak duck, non-indigenous Lombok ducks, growth rate, feedconversion

\section{PENDAHULUAN}

Telur asin Lombok terkenal hingga keluar daerah. Yang menjadi permasalahan adalah tidak terpenuhinya permintaan akan telur asin. Tidak terpenuhinya permintaan tersebut karena bahan untuk membuat telur asin yang berupa telur itik yang dibeli dari para peternak itik tidak cukup tersedia. Dari pihak peternak itik, kurangnya persediaan telur itik tersebut karena kurangnya kemampuan untuk memproduksi telur berhubung jumlah itiknya terbatas.

Kata kunci pada usaha peternakan itik di Lombok, adalah pengetahuan teknis beternak itik, bibit, pakan, modal usaha, pengetahuan/ketrampilan berwira usaha.

Pengetahuan teknis beternak itik mutlak harus dikuasai oleh peternak itik. Bibit harus selalu tersedia dalam jumlah yang cukup dan berkualitas. Bahan pakan utama, berupa dedak halus, harus selalu tersedia dalam jumlah yang cukup dan kualitas yang baik serta dengan harga yang terjangkau oleh peternak. Modal usaha harus tersedia cukup agar dapat memenuhi skala usaha beternak itik, sehingga dapat melewati titik impas usaha (break event point). Pengetahuan/ketrampilan berwira usaha harus dikuasai oleh peternak unggas, seperti cara pengadaan modal dan sarana 
produksi, tatalaksana usaha beternak, pemasaran hasil.

Pada kenyataannya semua kata kunci untuk sukses beternak itik tersebut sebagian besar tidak dapat dipenuhi oleh para peternak itik. Pengetahuan teknis beternak itik pada umumnya didapat dari orang tuanya, bibit itik seadanya dan dalam jumlah yang kecil, pakan sering tidak mampu membeli, modal usaha kecil, dan pengetahuan/ketrampilan berwira usaha minim. Info dari Direktorat Kredit, BPR dan UMKM Bank Indonesia bahwa titik pulang pokok / impas dari usaha itik petelur konvensional adalah $49.502 \mathrm{~kg}$ telur (Anonim, 2016).

Kondisi yang demikian tersebut menyebabkan adanya pola usaha sebagai berikut. Peternak membeli bibit ternak seadanya, dipelihara hingga besar dan bertelur. Begitu itik berhenti bertelur pada masa bertelur tahap pertama itik mengalami rontok bulu. Pada saat rontok bulu itik tidak memberi keuntungan pada peternak karena tidak bertelur. Peternak tidak mampu membeli pakan ternak karena tidak ada uang untuk beli. Karena tidak mampu memberi pakan itik maka itik dijual. Cara yang demikian peternak sebetulnya rugi, karena itik memiliki tiga masa produksi telur (Anonim, 2010). Peternak rugi dari dua hal, pertama rugi telah mengeluarkan biaya untuk membesarkan itik cukup mahal, kedua rugi tidak dapat memanen telur pada masa peneluran yang berikutnya. Tetapi peternak tidak ada pilihan lain untuk menjual itiknya yang sedang rontok bulu karena tidak ada uang untuk membeli pakan itik.

Dari temuan di lapangan pada saat tim peneliti Fakultas Peternakan dari Bidang Kajian Pemuliaan Ternak melakukan kajian tentang itik di Lombok, di Desa Pringgasela Lombok Timur pada tahun 2014 didapatkan info bahwa ada itik yang diduga asli Lombok, karena sudah diternakkan oleh penduduk setempat selama tiga generasi, dan tidak pernah mengawinkan dengan ternak itik lainnya.
Oleh Mamiq Zul, pemiliknya, itiknya dinamakan "itik sasak", disesuaikan dengan nama suku penduduk asli di Lombok.Beberapa peternak itik yang ikut memelihara itik tersebut mengatakan bahwa produksi telur itik sasak tidak kalah dengan itik-itik pendatang.

Untuk mengatasi salah satu masalah dari dari usaha peternakan yaitu masalah kekurangan bibit itik dan sekaligus melestarikan plasma nutfah, perlu dilakukan pengkajian tentang penampilan itik sasak dengan itik-itik pendatang yang banyak terdapat di lombok yaitu itik campbel, mojosari, alabio dan itik hasil persilangan itik mojosaro dengan itik alabio yang dikenal dengan nama itik MA. Pengkajian dilakukan dalam dua tahap. Tahap pertama mengkaji tentang pertumbuhan badan, tahap kedua mengkaji tentang tingkat produksi telur. Penelitian ini merupakan kajian yang pertama. Tingkat pertumbuhan badan diukur lewat tingkat pertambahan bobot badan dan pertumbuhan bagian-bagian badan yaitu tingkat pertambahan panjang dan diameter shank, serta panjang jari tengah.Sebagai pengarah dari kajian ini ditarik hipotesis sebagai berikut:

H0: Tidak ada perbedaan pertumbuhan badan antara itik sasak, itik campbell, itik mojosari, itik MA, dan itik alabio

HA: Ada perbedaan pertumbuhan badan antara itik sasak, itik campbell, itik mojosari, itik MA, dan itik alabio

\section{MATERI DAN METODE}

\section{Materi}

Materi penelitian:

- Itik DOD (umur satu hari) betina sebanyak 250 ekor, terdiri atas: itik sasak, itik cambel,itik mojosari, itik MA, alabio, masing-masing 50 ekor.

Lokasi penelitian:

- Penelitian akan dilaksanakan di Desa Pengenjek, Kecamatan Pringgarata, Kabupaten Lombok Tengah. 


\section{Bahan dan peralatan}

Bahan:

○ Pakan itik : BR1, KLK itik, jagung, dedak padi halus, air minum.

Peralatan:

○ Tempat pakan dan tempat minum itik

- Kandang pembesaran

○ Jangka sorong digital

- Alat timbang pakan kapasitas $50 \mathrm{~kg}$ dengan kepekaan 10 gram

- Alat timbang badan kapasitas $5 \mathrm{~kg}$ dengan kepekaan 1 gram

\section{Variabel yang diamati}

Pada penelitian ini diamati:

- Pertambahan bobot badan per minggu dari DOD hingga umur 10 minggu

- Pertambahan ukuran bagian badan dari DOD hingga umur 10 minggu:

- panjang metatarsus (shank),

- diameter shank

- panjang jari tengah

- Konversi pakan

Cara mengamati/mengukur variabel:

- Pertumbuhan badan

- Pertambahan bobot badan per minggu

- Menimbang bobot badan tiap minggu. Penimbangan dilakukan pagi hari sebelum itik diberi makan. Selisih antara penimbangan antar minggu merupakan pertambahan bobot badan per minggu

- Pertambahan ukuran bagian-bagian badan

Untuk pengukuran bagian-bagian badan digunakan jangka sorong

- Panjang metatarsus (shank) dan jari tengah

- Diukur dari ujung yang satu ke ujung yang satunya lagi

- Diameter metatarsus

- Diukur pada bagian metatarsus yang terlebar

- Konversi pakan

Konversi pakan dihitung tiap minggu
- Menimbang pakan yang akan diberikan ke itik selama satu minggu

- Mengambil sisa pakan tiap pagi hari sebelum diberi pakan yang baru. Sisa pakan dikeringkan, sesudah kering dikumpulkan dalam satu tempat kemudian ditimbang.

- Menghitung asupan pakan (feed intake) :

= bobot pakan yang diberikan bobot sisa pakan

- Menghitung konversi pakan:

Bobot pakan yang diasup tiap minggu dibagi pertambahan bobot badan tiap mingu

\section{Metode}

Semua DOD dari kelima bangsa itik setelah diberi nomor, masing-masing dimasukkan pada kandang pembesaran. Masing-masing kandang berisi 50 ekor. Di dalam kandang sudah disiapkan tempat pakan dan tempat minum. Lingkungan dibuat sama (sistem pemeliharaan, kandang, dan pakan)

\section{Pemberian pakan:}

Pakan diberikan dua kali per hari, pagi dan sore.Minggu I diberi pakan komersial BR1 dengan kandungan protein $20 \%$ dan energi metabolisme (EM) $2800 \quad \mathrm{kkal} / \mathrm{kg}$ pakan.Minggu II-VI diberi pakan campuran konsentrat KLK untuk itik masa pertumbuhan tiga bagian dan dedak halus 7 bagian (kandungan protein $20 \%$, energi $2.800 \mathrm{kkal} / \mathrm{kg}$ pakan). Minggu VII-X diberi pakan campuran KLK satu bagian, dedak halus sembilan bagian (kandungan protein 14-15\%, energi $2800 \mathrm{kkal} / \mathrm{kg}$ pakan).

\section{Pengamatan:}

- Pengamatan dilakukan sejak dari itik umur satu hari (DOD) hingga umur 10 minggu, berupa penimbangan dan pengukuran.

Penimbangan:

- Dilakukan penimbangan pakan yang akan diberikan dan sisa pakan untuk mengetahui banyaknya asupan pakan. 
- Dilakukan penimbangan dan pengukuran pada DOD, selanjutnya dilakukan penimbangan badan tiap minggu hingga umur 10 minggu

- Pengamatan pertumbuhan bulu dilakukan setiap minggu

\section{Rancangan penelitian:}

- Metode penelitian menggunakan metode rancangan percobaan dengan satu faktor perlakuan, dengan:

- Perlakuan berupa macam bangsa itik (lima bangsa itik)

- Ulangan 50

- Rancangan lingkungan: rancangan acak lengkap (RAL)

- Analisis data: data dianalisis menggunakan analisis varian

- Apabila hasilnya signifikan dilakukan uji lanjut Duncan

\section{HASIL DAN PEMBAHASAN}

Setioko et al. (2001) menyatakan bahwa pertumbuhan itik sangat dipengaruhi oleh faktor genetis, faktor lingkungan (pakan yang dikonsumsi, lingkungan sekitar, dan sistem perkandangan). Pada penelitian ini semua faktor lingkungan seperti jenis dan sistem pemberian pakan, luas kandang, dan penjagaan kesehatan diseragamkan, sehingga bila terjadi perbedaan penampilan pasti disebabkan oleh faktor genetik.
Pertumbuhan badan dalam penelitian ini diejawantahkan dalam bentuk bobot badan dari umur satu hingga sepuluh minggu, serta besar ukuran-ukuran tubuh lainnya, yaitu: panjang shank, ukuran besar shank, dan panjang jari tengah shank.

\section{Bobot badan}

Data bobot badan dari minggu ke 1 hingga minggu ke 10 pada semua bangsa itik mengalami pertambahan (lihat Gambar 1). Dari hasil analisis ragam disimpulkan bahwa pada umur 10 minggu bobot badan itik sasak dan itik campbell lebih kecil secara nyata $(\mathrm{P}<0,05)$ daripada itik mojosari, MA, dan alabio. Dari lebih kecilnya bobot badan, menandakan bahwa itik sasak dan itik campbell benar-benar itik tipe petelur sejati, karena ciri-ciri itik petelur antara lain adalah berbadan kecil (Anonim, 2014).

Itik alabio merupakan hasil persilangan antara itik kalimantan dengan itik peking (Hetzel, 1985). Itik peking adalah itik pedaging, sehingga itik alabio adalah itik dwiguna, penghasil telur dan penghasil daging. Tipe itik pedaging antara lain berbadan besar. Ukuran badan itik tipe dwiguna berbadan lebih besar daripada itik petelur, tetapi lebih kecil daripada itik tipe pedaging.

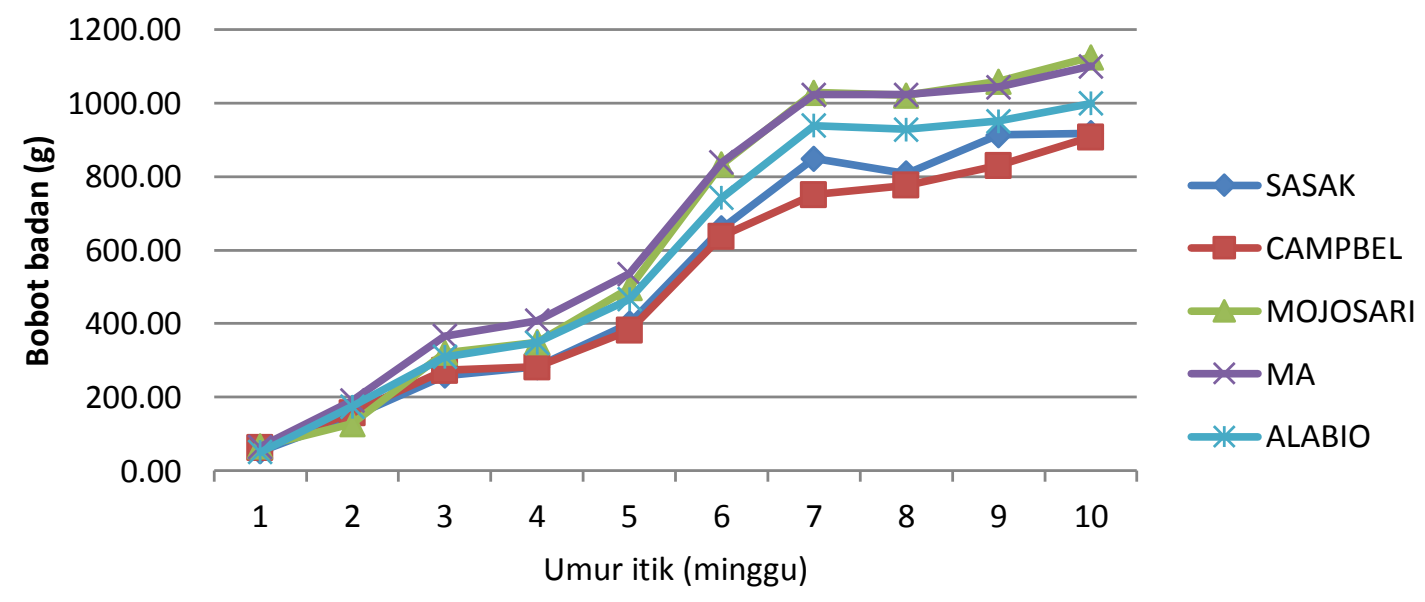

Gambar 1. Grafik pertumbuhan badan itik dari umur 1 - 10 minggu

Keragaman bobot badan
Keragaman bobot badan merupakan salah satu syarat dari seleksi 
ternak. (Falconer, 1986). Dari data pada Tabel 3dapat disimpulkan bahwa itik sasak dan itik campbell dapat diseleksi untuk meningkatkan bobot badannya, karena rata-rata koefisien bobot badan (yang menggambarkan tingkat keragaman relatif) untuk keduanya relatif tinggi, terutama pada saat itik berumur empat minggu.
Pada itik mojosari, MA dan alabio walaupun $\mathrm{h}^{2}$ sebesar $40 \%$, tetapi koefisien variasi tidak terlalu besar hanya $10-13 \%$, sehingga bila dilakukan seleksi berdasarkan bobot badan respon seleksinya tidak sebesar yang terjadi pada itik sasak dan itik campbell.

Tabel 3. Koefisien keragaman bobot badan pada itik sasakdan itik pendatang pada umur 110 minggu

\begin{tabular}{crrrrr}
\hline $\begin{array}{c}\text { Umur } \\
(\mathrm{minggu})\end{array}$ & \multicolumn{5}{c}{ Koefisien keragaman (\%) bobot badan pada itik } \\
\hline 1 & \multicolumn{1}{c}{ sasak } & campbell & mojosari & \multicolumn{1}{c}{ MA } & \multicolumn{1}{c}{ alabio } \\
\hline 2 & 19,86 & 18,11 & 8,98 & 24,3 & 19,99 \\
3 & 21,78 & 21,53 & 10,91 & 22,87 & 17,98 \\
4 & 24,2 & 22,18 & 9,7 & 14,31 & 19,1 \\
5 & 24,64 & 25,58 & 11,87 & 12,91 & 17,72 \\
6 & 22,72 & 21,24 & 12,44 & 9,98 & 13,83 \\
7 & 21,72 & 18,94 & 8,38 & 9,34 & 13,07 \\
8 & 19,15 & 17,92 & 9,02 & 9,07 & 10,08 \\
9 & 19,22 & 17,2 & 9,11 & 7,57 & 8,9 \\
10 & 16,72 & 15,62 & 10,03 & 8,22 & 8,34 \\
Rata-rata & 16,97 & 13,19 & 9,62 & 8,73 & 8,04 \\
\hline
\end{tabular}

\section{Pertambahan bobot badan (PBB)}

Sesuai dengan pendapat Rosilawati et al. (2010) pertumbuhan badan paling cepat pada masa starter, untuk kemudian melambat. Pada Gambar 2di umur antara 5-6 minggu semua bangsa itik mengalami pertambahan bobot badan yang paling tinggi. Keadaan ini sangat mirip dengan apa yang dialami pada persilangan antara itik alabio dan Peking yang mengalami penambahan bobot badan paling banyak pada umur 6 minggu (Susanti, 2012) (lihat Tabel 1 halaman 8). Pertambahan bobot badan itik sasak dan campbell lebih rendah $(\mathrm{P}<0,05)$ daripada pertambahan bobot badan itik mojosari, MA, dan itik alabio. Dibandingkan dengan kelima bangsa itik pada penelitian ini, puncak pertambahan bobot badan itik Cihatuep asal Garut Jawa Barat terjadi lebih awal yaitu terjadi pada umur empat minggu (Wulandari, 2005) 
Jurnal Ilmu dan Teknologi Peternakan Indonesia Volume 4 (1): 181-190; Juli 2018

ISSN: 2460-6669

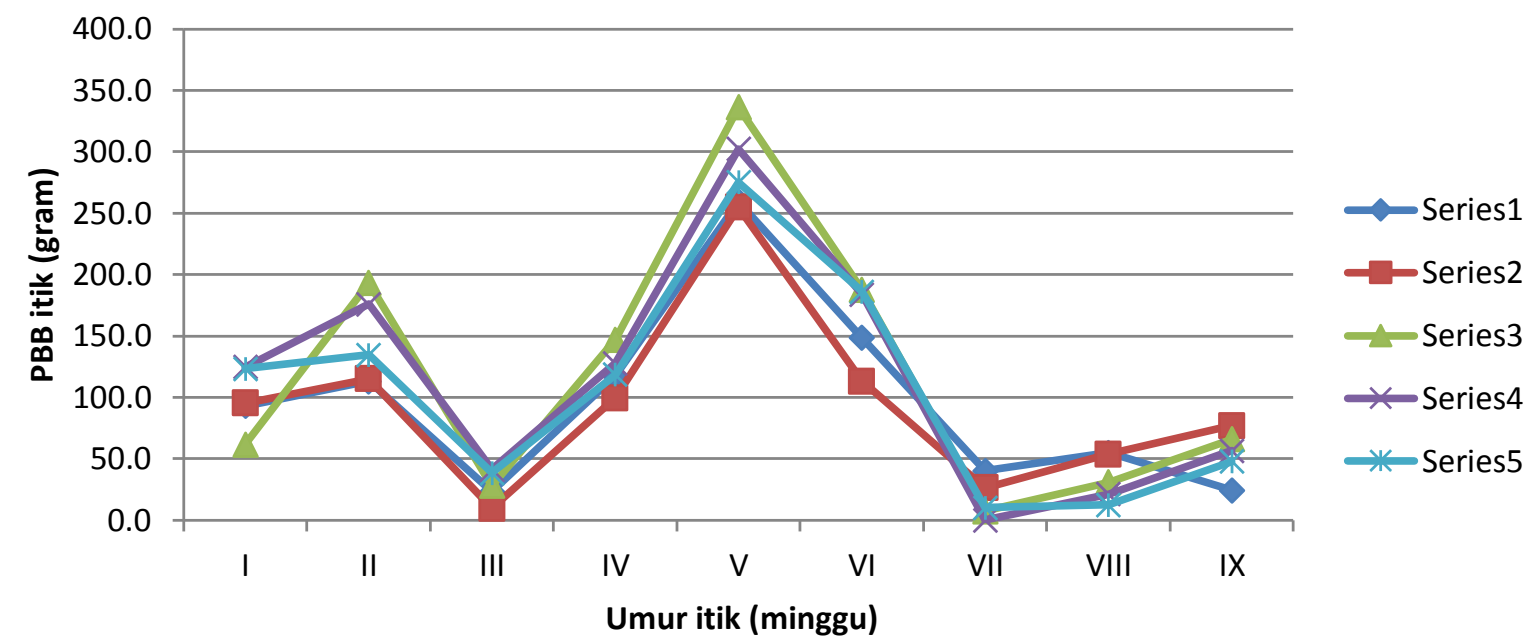

Gambar 2. Pertambahan bobot badan itik sasak dan itik pendatangPada umur $1-10$ minggu

Keterangan

I : umur antara 1-2 minggu

II : umur:antara 2-3 minggu

III : umur antara 3-4 minggu

IV : umur antara 4-5 minggu

$\mathrm{V}$ : umur antara 5-6 minggu

VI : umur antara 6-7 minggu

VII : umur antara 7-8 minggu

VIII: umur antara 8-9 minggu

IX : umur antara 9-10 minggu

Grafik pada Gambar 2 seharusnya tidak ada penurunan penambahan bobot badan pada masa starter. Pada kenyataannya terlihat ada penurunan penambahan bobot badan pada antara umur tiga dengan empat minggu. Keadaan tersebut terjadi karena adanya stres pada semua itik, yang disebabkan oleh pemberian wing tag dan pemindahan tempat dari kandang indukan ke kandang pembesaran. Pemasangan wing tag baru dipasang pada umur 3 minggu karena pada umur sebelumnya terlalu tipis kulit yang akan dipasangi wing tag.

\section{Panjang shank}

Dari hasil analisis ragam tidak terdapat perbedaan yang nyata $(\mathrm{P}>0,05)$ panjang shank antara itik sasak dengan itik-itik pendatang.

Dari Gambar 3terlihat bahwa panjang shank dari umur 1 minggu hingga umur 10 minggu mengalami kenaikan $253,86 \%$ atau 2,5 kali lebih. 
Jurnal Ilmu dan Teknologi Peternakan Indonesia Volume 4 (1): 181-190; Juli 2018

ISSN: 2460-6669

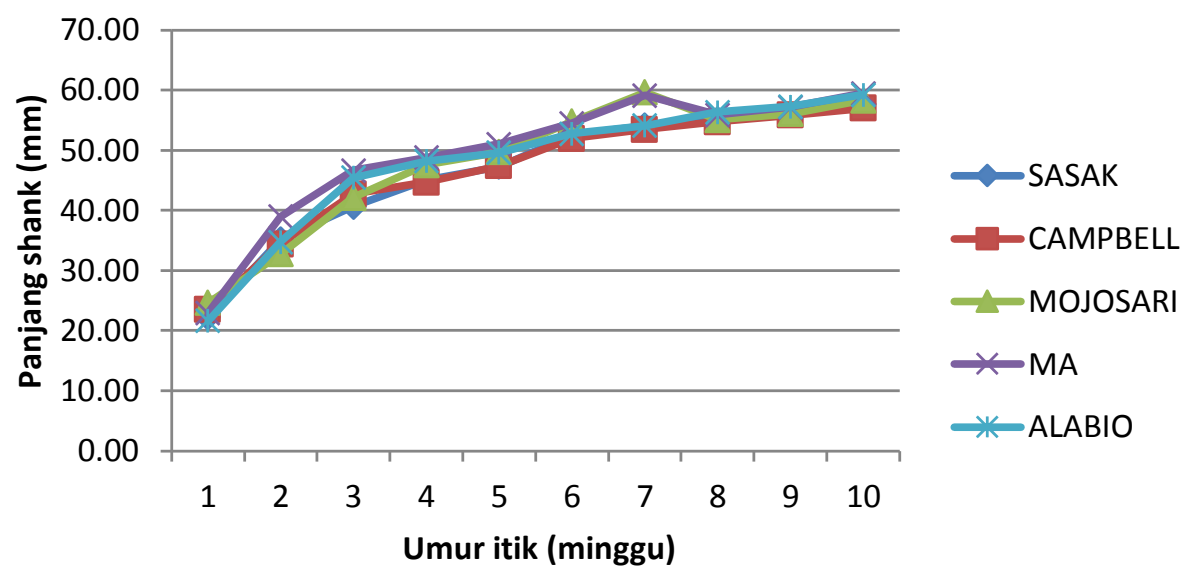

Gambar 3. Grafik panjang shank itik (mm) pada umur 1 - 10 minggu

Namun bilamana dilihat pertambahan panjangnya per minggu, pertambahan panjang shank tertinggi hanya terjadi pada

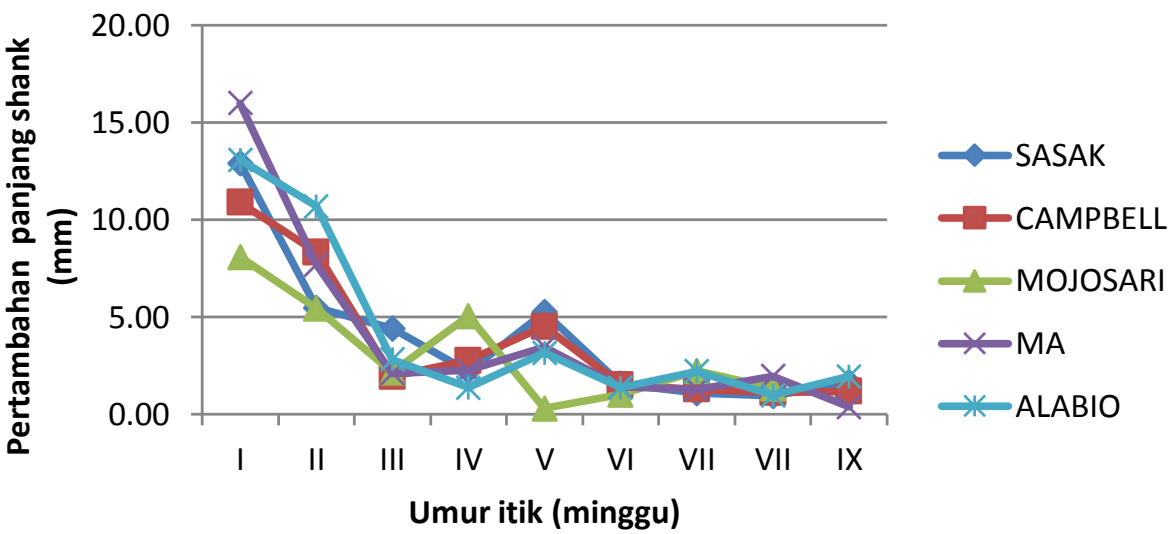

Gambar 4.Grafik pertambahan panjang shank (PPS) itik umur 1 - 10 minggu

Pertambahan panjang shank relatif paling inggi terjadi pada itik alabio, dan terendah terjadi pada itik mojosari.

Pertambahan panjang shank relatif itik sasak dan itik MA berada di antara itik campbell dan itik alabio.

Tabel 8. Pertambahan panjang shank itik sasak dan itik pendatang

\begin{tabular}{cccc}
\hline & \multicolumn{2}{c}{ Rata-rata panjang shank (mm) pada } & Pertambahan relatif \\
& Umur 1 minggu & Umur 10 minggu & $(\%)$ \\
\hline sasak & 22,26 & 57,76 & $259,50^{\mathrm{a}}$ \\
campbell & 23,48 & 57,02 & $242,81^{\mathrm{b}}$ \\
mojosari & 24,63 & 58,32 & $236,80^{\mathrm{c}}$ \\
MA & 22,96 & 59,50 & $259,14^{\mathrm{a}}$ \\
alabio & 21,63 & 59,24 & $273,91^{\mathrm{d}}$ \\
\hline
\end{tabular}

Keterangan: Superscript yang berbeda pada kolom yang sama menunjukkan perbedaan yang nyata 


\section{Diameter Shank}

Ukuran pertumbuhan bagian-bagian tubuh selain memanjang juga membesar. Begitu pula yang terjadi pada pertumbuhan

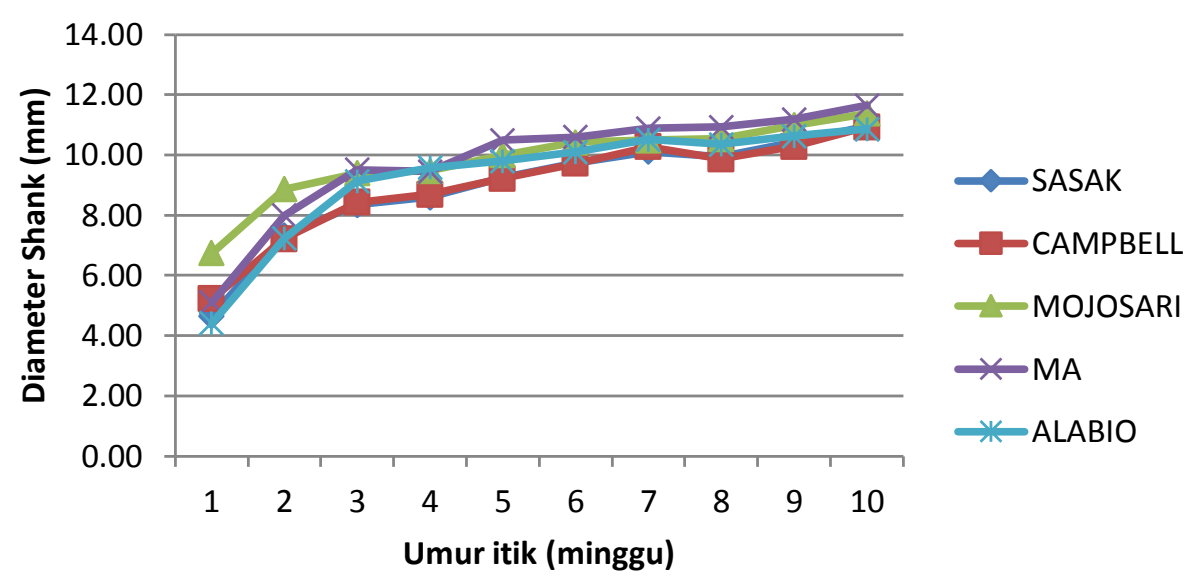

Gambar 5. Grafik diameter shank itik sasak dan itik pendatangpada umur 1 -10 minggu

Dari hasil analisis ragam tidak

Daridata pada Tabel 9terlihat bahwa rata-rata pertambahan ukuran diameter shank untuk semua bangsa itik dari umur 1 hingga 10 minggu sebesar lebih dari dua kali lipat $(217,43 \%)$. shank, selain makinpanjang juga makin besar, dalam hal ini direpresentasikan dalam dimensi diameter shank.

Tabel 10. Pertambahan diameter shank $(\mathrm{mm})$ itik sasak dan itik pendatang umur $1-10$ minggu

\begin{tabular}{cc}
\hline Bangsa & Pertambahan diameter shank \\
itik & relatif $(\%)$ \\
\hline sasak & $135,70^{\mathrm{a}}$ \\
campbel & $109,39^{\mathrm{c}}$ \\
mojosari & $68,59^{\mathrm{d}}$ \\
MA & $127,79^{\mathrm{b}}$ \\
alabio & $145,70^{\mathrm{a}}$ \\
\hline
\end{tabular}

Keterangan: Superscript yang berbeda pada kolom yang sama menunjukkan perbedaan yang nyata $(\mathrm{P}<0,05)$

Pertambahan diameter shank relatif itik sasak tidak berbeda nyata $(\mathrm{P}>0,05)$ dengan itik alabio, lebih besar secara nyata daripada itik campbell, mojosari, dan MA. Pertambahan diameter shank relatif itik mojosari paling rendah, hanya $68,59 \%$.

\section{Panjang Jari Tengah}

Dari grafik pada Gambar 6 terlihat panjang jari tengah shank pada semua bangsa itik dari umur satu hingga 10 minggu rata-rata naik $181,90 \%$. Dari analisis statistik didapatkan pertambahan relatif panjang jari tengah sasak dan campbell lebih sedikit $(\mathrm{P}<0,05)$ dari pada ketiga bangsa itik lainnya. 


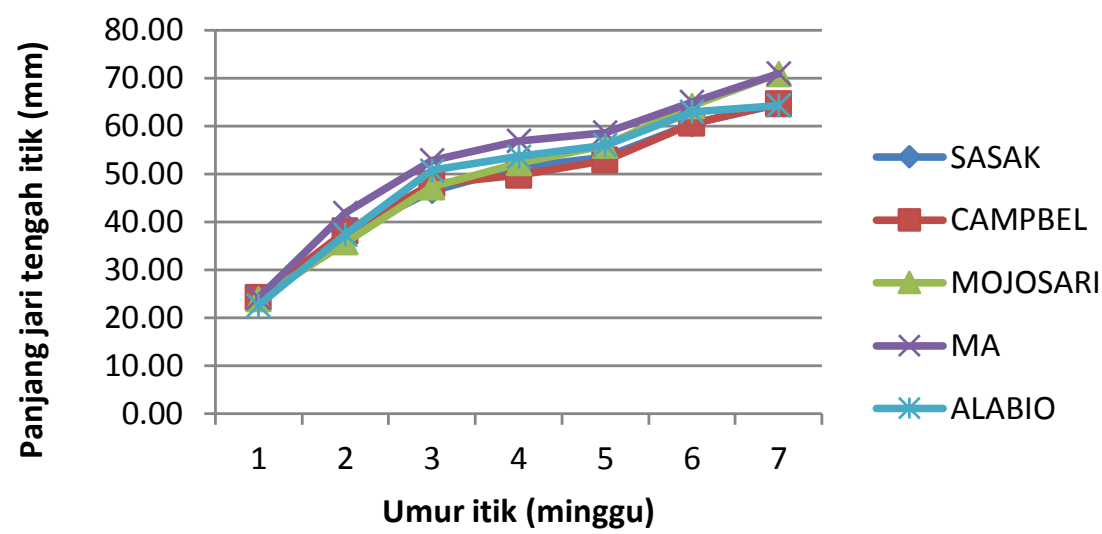

Gambar 6. Panjang jari tengah itik sasak dan itik pendatangpada umur $1-10$ minggu

\section{Konversi Pakan}

Tabel 12. Rata-rata konversi pakan dan PBB pada itik sasak dan itik pendatang

\begin{tabular}{lcc}
\hline \multicolumn{1}{c}{ Bangsa } & $\begin{array}{c}\text { Rata-rata } \\
\text { Konversi Pakan } \\
\text { (gram pakan/gram PBB) }\end{array}$ & $\begin{array}{c}\text { Rata-rata Pertambahan BB } \\
\text { Per ekor/minggu } \\
\text { (gram) }\end{array}$ \\
\hline sasak & $3,60^{\mathrm{a}}$ & $96,1^{\mathrm{a}}$ \\
campbell & $3,90^{\mathrm{b}}$ & $93,8^{\mathrm{a}}$ \\
mojosari & $4,04^{\mathrm{b}}$ & $117,6^{\mathrm{c}}$ \\
MA & $4,06^{\mathrm{b}}$ & $114,9^{\mathrm{c}}$ \\
alabio & $3,66^{\mathrm{a}}$ & $105,2^{\mathrm{b}}$ \\
\hline
\end{tabular}

Keterangan: Superscript yang berbeda pada kolom yang sama menunjukkan perbedaan yang nyata $(\mathrm{P}<0,05)$

Dari Tabel 11dapat diketahui bahwa itik sasak dan itik alabio memiliki KP yang lebih kecil daripada ketiga bangsa lainnya, yang berarti lebih ekonomis dalam pemberian pakan. Pada bangsa itik sasak dan alabiokonversi pakan lebih besar daripada KP pada mojosari dan MA. Seharusnya KP kedua bangsa itik tersebut tidak sebesar itu, karena PBB nya lebih besar daripada bangsa itik yang lain berhubung menurut Amin et al. (2013) ada korelasi negatif antara KP dengan PBB. Lebih besarnya KP kedua bangsa itik tersebut karena kepadatan kandang lebih longgar daripada kandang itik yang lain. Hal tersebut terjadi karena jumlah itik mojosari dan MA lebih sedikit, jumlah DOD yang datang tidak sesuai dengan jumlah DOD yang dipesan.

\section{SIMPULAN}

1. Pola pertumbuhan badan itik:

a. Bobot badan:

i. Semua bangsa itik pertambahan bobot badan (PBB) menaik hingga umur antara 5-6 minggu. PBB sasak dan campbell paling rendah.

ii. Pada umur 10 minggu bobot badan itik sasak dan itik campbell lebih $(\mathrm{P}<0,05)$ daripada itik mojosari, MA, dan alabio.

b. Panjang shank

i. Rata-rata panjang shank untuk semua bangsa itik dari umur 1 minggu hingga umur 10 minggu mengalami kenaikan 253,86\%.

ii. Pertambahan panjang shank tertinggi hanya terjadi pada 
awal minggu pertama saja, untuk selanjutnya pertambahan panjang shank makin mengecil.

iii. Pertambahan panjang shank relatif itik sasak dan itik MA berada di antara itik campbell dan itik alabio, tertinggi pada itik alabio dan terendah pada itik mojosari.

c. Diameter shank

i. Rata-rata pertambahan ukuran diameter shank untuk semua bangsa itik umur 1 hingga 10 minggu $217,43 \%$.

ii. Tidak ada perbedaan $(\mathrm{P}>$ $0,05)$ diameter shank antara itik sasak dengan itik pendatang yang lain pada umur 10 minggu.

d. Jari tengah

i. Panjang jari tengah shank pada semua bangsa itik dari umur satu hingga 10 minggu rata-rata naik $181,90 \%$.

ii. Pertambahan relatif panjang jari tengah sasak dan campbell lebih sedikit $(\mathrm{P}<$ $0,05)$ dari pada ketiga bangsa itik lainnya.

2. Konversi pakan

- Konversi pakan itik sasak, campbell, mojosari, MA, dan alabio berturutturut : 3,$60 ; 3,90 ; 4,04 ; 4,06$, dan 3,66.

\section{DAFTAR PUSTAKA}

Amin, I., Nasich,M., dan Marjuki. 2013. Pertambahan Bobot Badan dan Konversi Pakan Sapi Limousin Cross dengan Pakan Tambahan Probiotik. Skripsi. Fakultas Peternakan, Universitas Brawijaya. Malang.

Anonim. 2010. Menanti Masa Peneluran Pertama http://sentralternak.com/index. php/2010/04/19/menanti-masapeneluran-pertama/Diunduh 10 Desember 2016.
Anonim. 2014. Tentang Bebek dan Ciri Cirinya. http://www.situspeternakan.com/http://www.situspeternakan.com/2014/04/tentangbebek-dan-ciri- cirinya.html. Unduh 8 Des 2016

Anonim. 2016. Pola Pembiayaan Usaha Kecil (PPUK). Usaha itik Petelur (Pola Pembiayaan Konvensional). Direktorat Kredit, BPR dan UMKM. BANK Indonesia. Diunduh 10 Desember 2016.

Falconer, D.S. 1986. Introduction to Quantitative Genetics. Second Edition. Longman Scientific \& Technical. Hong Kong. Pp. 171172.

Hetzel DJS. 1985. Duck breeding strategies - the Indonesian example. In: Farrel d Stapleton P. (Eds). Duck Production Science and World Practice. University of New England: pp.204- 223.

Rositawati I, Saiful, N dan Muharlien. 2010. Upaya peningkatan performa itik mojosari periode starter melalui penambahan temulawak pada pakan. Jurnal Ternak Tropika, 11(2): 32-40.

Setioko, A.R., L.H. Prasetyo, B. Bramantiyo dan M. Purba.2001. Koleksi dan Karakterisasi Sifat-Sifat Beberapa Jenis Itik. Kumpulan Hasil-hasil Penelitian APBN Tahun Anggaran 2001. Balai Penelitian Ternak Ciawi. Bogor.

Susanti, T. 2012. Keterkaitan genetis sifat rontok bulu dengan produksi telur pada itik alabio dan itik peking. Disertasi. Sekolah Pascasarjana Institut Pertanian Bogor. Bogor.

Wulandari, W.A.2005. Kajian Karakteristik Itik Cihateup. Tesis. Program PascaSarjana. Instutut Pertanian Bogor. Bogor. 